\title{
Radicular Cyst (Periapical Cyst): A Case Report
}

\author{
Yamini Kanipakam ${ }^{1}$, Santha D Arumugam² ${ }^{2}$, Prem L Kulandairaj ${ }^{3}$, Sivaramakrishnan Muthanandam ${ }^{4}$
}

\begin{abstract}
Radicular cyst is one of the most common odontogenic cyst found in the jaws. It is inflammatory in nature and found mostly in the nonvital tooth. It usually presents at a later stage in life because the formation of the cyst is the last step in the progression of inflammatory events after a periapical infection. This present case was with swelling, and the cyst was removed surgically under local anesthesia. Based on histopathological findings, it was diagnosed as a radicular cyst.
\end{abstract}

Keywords: Odontogenic cyst, Periapical infection, Radicular cyst.

Journal of Scientific Dentistry (2019): 10.5005/jp-journals-10083-0908

\section{INTRODUCTION}

Radicular cyst is a common inflammatory odontogenic cyst, which arises from epithelial rest of Malassez due to pulpal necrosis. World Health Organization, classified cysts in the jawbones as a developmental, neoplastic, and inflammatory origin. Root canal infections may cause radicular cyst, few radicular cysts can be treated by conventional root canal therapy, and large radicular cyst is managed surgically. The present case is intended to discuss the radicular cyst and its histological features.

\section{Case Description}

A 35-year female reported to our college with a chief complaint of swelling in the right lower back teeth region for the past 30 days. Patient was normal before 30 days then she noticed a swelling in the right lower back teeth region since 1 month, which was initially smaller in size then gradually attained to present size. The swelling was painful before 20 days about 3-4 days, which was sudden in onset, pricking type, intermittent in nature, aggravate while chewing food, and relieves on taking medications. History of body ache since 1-year, and she was under medication for body ache, symptomatically.

Solitary swelling over the right lower third of the face, size approximately $3 \times 2.5 \mathrm{~cm}$ in size, oval in shape, extending $0.5 \mathrm{~cm}$ away from the corner of the lip till $3 \mathrm{~cm}$ away from the tragus of the ear anteroposteriorly and superoinferiorly extending $1 \mathrm{~cm}$ away from the right corner of the lip till the lower border of the mandible, with ill-defined borders, skin over the swelling appear normal. On palpation, all inspectors finding in relation to the site, size, shape, extent, border, skin over the swelling are confirmed with a mild rise in local temperature, soft to bony hard in consistency (Fig. 1).

On examination, a single swelling over the right lower third of the face of size approximately $3 \times 2.5 \mathrm{~cm}$ in size, oval in shape, extending $0.5 \mathrm{~cm}$ away from the corner of the lip till $3 \mathrm{~cm}$ away from the tragus of the ear anteroposteriorly and superoinferiorly extending $1 \mathrm{~cm}$ away from the right corner of the lip till the lower border of the mandible, with ill-defined borders, skin over the swelling appear normal, soft to bony hard inconsistency and no tenderness on palpation (Fig. 2).

Intraoral periapical radiograph (IOPA) of 46 reveals loss of tooth structure involving the enamel, dentin, and pulp with well-defined solitary radiolucency around the apex of $45,46,47$ with corticated
${ }^{1-3}$ Department of Oral and Maxillofacial Pathology and Oral Microbiology, Indira Gandhi Institute of Dental Sciences, Sri Balaji Vidyapeeth (a Deemed University), Puducherry, India

${ }^{4}$ Department of Oral Pathology and Microbiology, Indira Gandhi Institute of Dental Sciences, Sri Balaji Vidyapeeth (a Deemed University), Puducherry, India

Corresponding Author: Yamini Kanipakam, Department of Oral and Maxillofacial Pathology and Oral Microbiology, Indira Gandhi Institute of Dental Sciences, Sri Balaji Vidyapeeth (a Deemed University), Puducherry, India, Phone: +91 9444848548, e-mail: dr.mini2711@ gmail.com

How to cite this article: Kanipakam Y, Arumugam SD, Kulandairaj PL, Muthanandam S. Radicular Cyst (Periapical Cyst): A Case Report. J Sci Den 2019;9(2):43-45.

Source of support: Nil

Conflict of interest: None

border, (suggestive of periapical cyst present 46) which was oval in shape with infected root stumps (Fig. 3).

Histopathologically squamous lining epithelium of variable thickness, hyperplastic epithelium, eosinophilic hyalinized

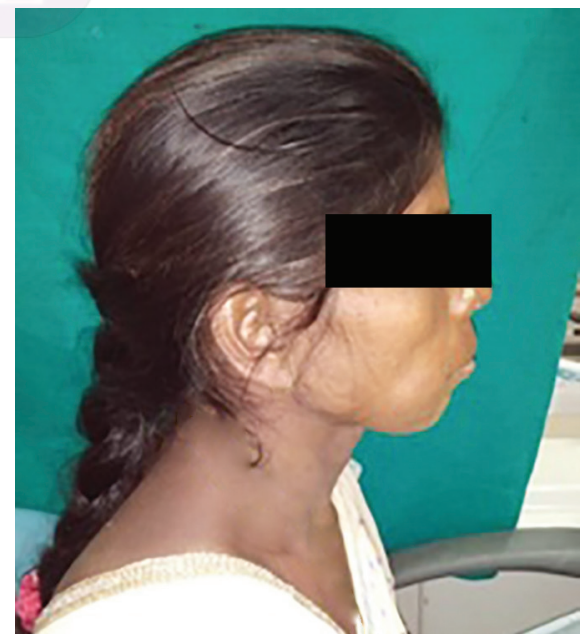

Fig. 1: Extraoral picture showing solitary swelling over the right lower third of the face approximately $3 \times 2.5 \mathrm{~cm}$ in size, oval in shape

() The Author(s). 2019 Open Access This article is distributed under the terms of the Creative Commons Attribution 4.0 International License (https://creativecommons. org/licenses/by-nc/4.0/), which permits unrestricted use, distribution, and non-commercial reproduction in any medium, provided you give appropriate credit to the original author(s) and the source, provide a link to the Creative Commons license, and indicate if changes were made. The Creative Commons Public Domain Dedication waiver (http://creativecommons.org/publicdomain/zero/1.0/) applies to the data made available in this article, unless otherwise stated. 


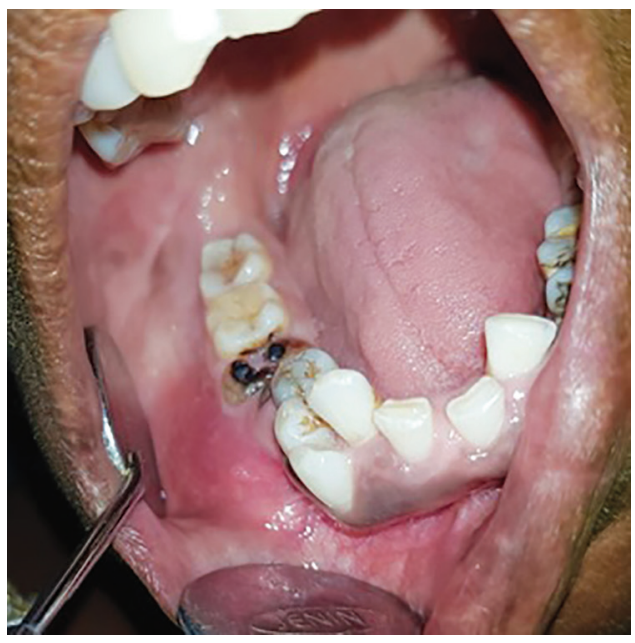

Fig. 2: Intraoral picture showing a solitary swelling of size approximately $1 \times 2 \mathrm{~cm}$

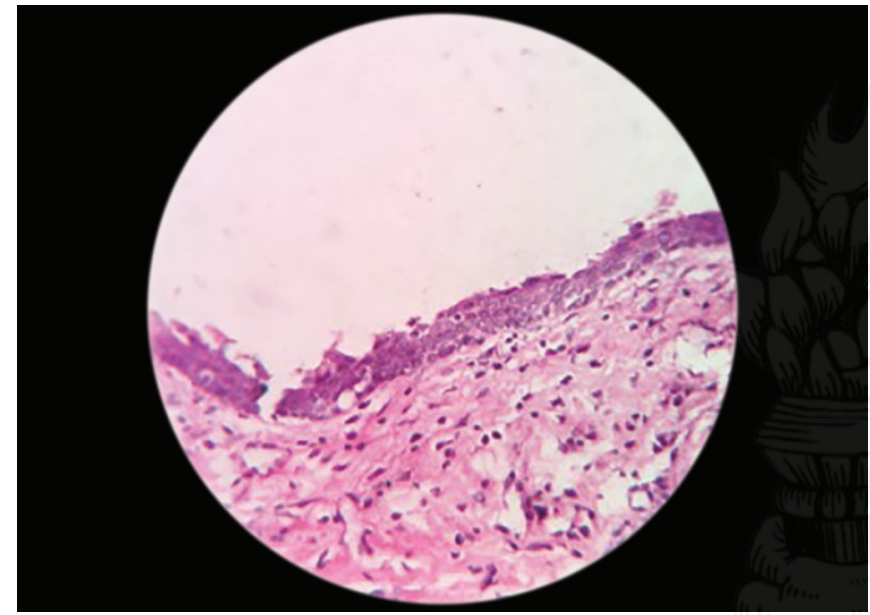

Fig. 4: Histopathological picture showing stratified squamous epithelium of variable thickness

material resembling hyaline bodies, and mucous cells. A few areas epithelium is thin with two to three layers of epithelial cells, apart from this, the lining epithelium exhibits eosinophilic hyalinized material resembling hyaline bodies and mucous cells. Whereas, few areas epithelium is thin with two to three layers of epithelial cells. The underlying connective tissue is edematous with plenty of chronic inflammatory cell infiltrate. Based on clinical, radiographical and $\mathrm{H} / \mathrm{P}$ consideration finally diagnosed as radicular cyst in relation to 46 (Figs 4 and 5).

\section{Discussion}

The cyst is defined as "a pathological cavity having a fluid, semifluid or gaseous contents and which is not created by the accumulation of pus." ${ }^{11}$ Radicular cyst considered as inflammatory cyst because of the caries tooth or trauma. The etiology of radicular cyst focuses on trauma or dental caries, which ends up in pulpal necrosis where the infection travels to the tooth apex of the root and form periapical granuloma periapical cyst secondary to the provocation of epithelial rest of Malassez through the local inflammation. ${ }^{2}$

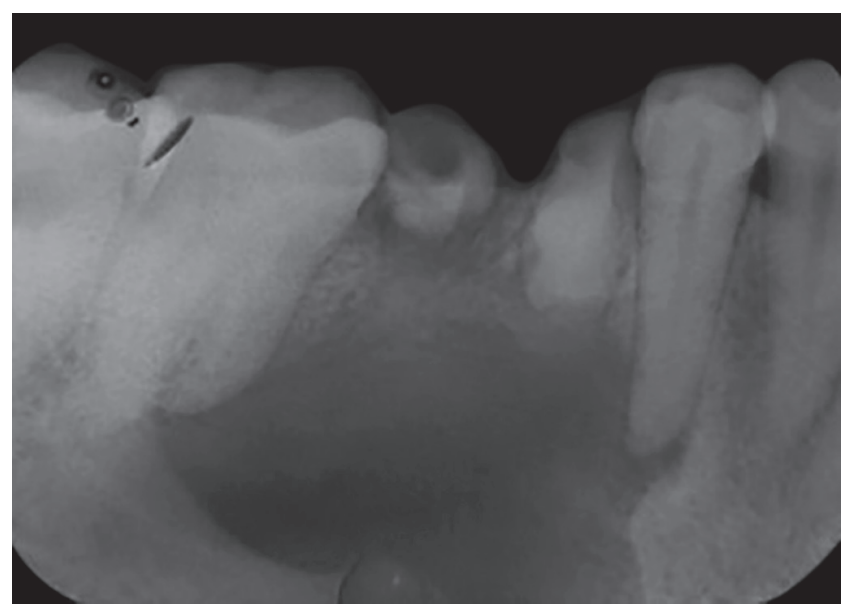

Fig. 3: Intraoral periapical radiograph of 46 reveals a well-defined unilocular radiolucency around the apex of 45, 46 involving the apex of mesial root of 47

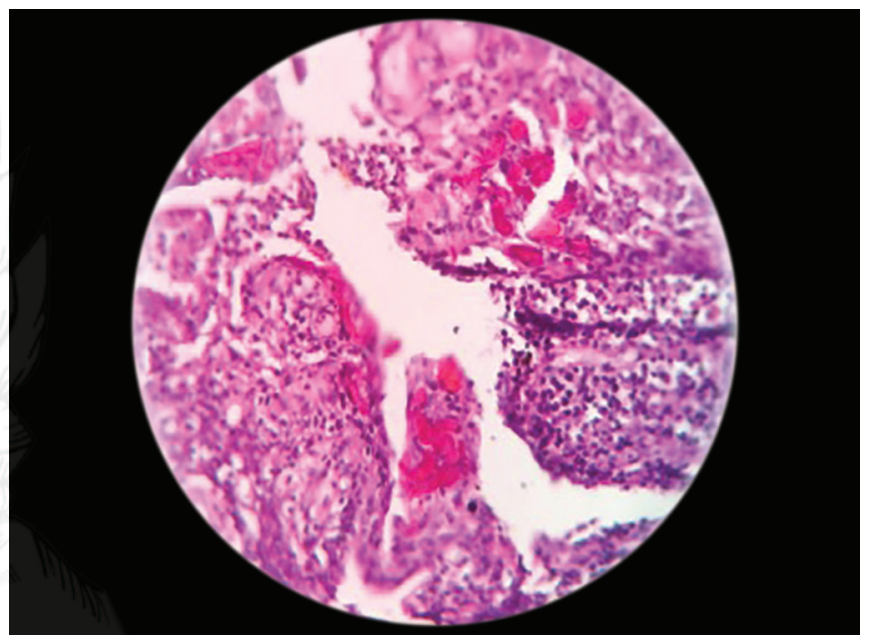

Fig. 5: Connective tissue is edematous with plenty of chronic inflammatory cell infiltrate

Radicular cysts are considered to be the most common cysts, $52-68 \%$ of all the cysts affecting the jaws, around $9 \%$ are true cysts and $6 \%$ pocket cysts. ${ }^{3}$ Prevalence is highest in the third decade of life, men are more commonly affected than women. ${ }^{4}$ The incidence of radicular cyst in a deciduous tooth seems to be low as compared with a permanent tooth. Shorter duration of primary teeth could be one of the reasons and easy drainage through the presence of numerous accessory canals. ${ }^{5}$

The pathogenesis of radicular cyst has been described in three phases; phase of initiation, cyst formation, and enlargement. ${ }^{6}$ However, two theories exist in cyst cavity formation. The "nutritional deficiency theory" is based on devoid of nutritional deficiency and the "abscess theory" that the proliferating epithelium lines an abscess cavity formed by tissue necrosis and lysis because of the innate nature of the epithelial cells to cover exposed connective tissue surfaces then the cyst grows by osmosis. Later diffuses into the cyst cavity to raise the intraluminal hydrostatic pressure well above the capillary pressure. The increased intracyst pressure may lead to bone resorption and expansion of the cyst. Pocket cysts with lumen open to the necrotic root canal can become larger than usual because osmotic pressure plays a potential factor in the development of radicular cysts. ${ }^{4}$ 
Clinically a patient with periapical cyst has no symptom until there is an acute inflammatory exacerbation, the cyst reaches a large size, followed by swelling. Mild sensitivity may be noted in the affected area. Movement and mobility of adjacent teeth can occur as the cyst enlarges. ${ }^{7}$ Radiographic feature reveals a welldefined unilocular radiolucency located periapical to a tooth with pulpal involvement. ${ }^{8}$

On histopathological examination, most of the radicular cysts are lined wholly or partly, by nonkeratinized-stratified squamous epithelium, this lining may be discontinuously ranging from 1 to 50 cell layers thick. In the early stages, the epithelial lining may show proliferation and arcading pattern with intense inflammatory infiltrate. In enlarging cysts, the lining becomes quiescent and fairly regular with a certain degree of differentiation to resemble simple stratified squamous epithelium. Keratin formation occurs rarely, if present, affects only a part of the cyst wall. In the proliferating epithelium, the inflammatory cell infiltrate consists predominantly of polymorphonuclear leukocytes. The adjacent fibrous capsule is infiltrated by chronic inflammatory cells. ${ }^{9}$

Periapical lesions and cyst-like lesions can be initially managed by nonsurgical endodontic treatment. In a few cases, surgical management might be necessary for a good prognosis. Better knowledge about microorganisms will helps in treatment and oral maxillofacial surgery practices. ${ }^{10}$ A follow-up of 1-2 years after treatment has to be done.

\section{References}

1. Shivhare P, Singh A, Haidry N, Yadav M, Shankarnarayan L. Multilocular radicular cyst - a common pathology with uncommon radiological appearance. J Clin Diagn Res 2016;10(3):ZD13-ZD15. DOI: 10.7860/ JCDR/2016/16031.7486.

2. Rajendran R. Shafer's textbook of oral pathology. Elsevier India; 2009.

3. Lin LM, Ricucci D, Kahler B. Radicular cysts review. JSM Dent Surg 2017;2(2):1017.

4. Latoo S, Shah AA, Jan SM, Qadir S, Ahmed I, Purra AR, et al. Radicular cyst. JK Sci 2009;11(4):187.

5. Mahesh BS, Shastry SP, Murthy PS, Jyotsna TR. Role of cone beam computed tomography in evaluation of radicular cyst mimicking dentigerous cyst in a 7-year-old child: a case report and literature review. Int J Clin Pediatr Dent 2017;10(2):213-216. DOI: 10.5005/ jp-journals-10005-1438.

6. Bava FA, Umar D, Bahseer B, Baroudi K. Bilateral radicular cyst in mandible: an unusual case report. J Int Oral Health 2015;7(2):61-63.

7. Neville BW, Damm DD, Allen CM, Chi AC. Oral and maxillofacial pathology. Elsevier Health Sciences; 2015.

8. Noda A, Abe M, Shinozaki-Ushiku A, Ohata Y, Zong L, Abe T, et al. A bilocular radicular cyst in the mandible with tooth structure components inside. Case Rep Dent 2019;2019:6245808. DOI: 10.1155/2019/6245808.

9. Harshitha KR, Varsha VK, Deepa C. Radicular cyst-A case report. Int J Appl Dent Sci 2015;1(4):20-22.

10. Tek M, Metin M, Sener I, Bereket C, Tokac M, Kazancioglu HO, et al. The predominant bacteria isolated from radicular cysts. Head Face Med 2013;9:25. DOI: 10.1186/1746-160X-9-25. 